\title{
Evaluation of Milk Compositional Quality and Mammary Gland Health of Dairy Herds in the Southwestern Brazilian Amazon
}

\author{
Luciana G. Brito ${ }^{1}$, José R. Vieira Júnior ${ }^{1}$, Fábio da S. Barbieri ${ }^{1}$, Rodrigo B. Rocha ${ }^{1}$, \\ Marivaldo R. Figueiró2, Websten C. da Silva ${ }^{3}$, Gilvânia L. O. Carvalho4, \\ José de Arimatéia Silva4, Guilherme N. Souza ${ }^{3}$ \\ ${ }^{1}$ Embrapa Rondônia, Porto Velho, Brazil \\ ${ }^{2}$ Embrapa Eastern Amazon, Belém, Brazil \\ ${ }^{3}$ Embrapa Dairy Cattle, Juiz de Fora, Brazil \\ ${ }^{4}$ Emater Rondônia, Porto Velho, Brazil \\ Email: ${ }^{*}$ luciana.gatto@embrapa.br
}

How to cite this paper: Brito, L.G., Júnior, J.R.V., da S. Barbieri, F., Rocha, R.B., Figueiró, M.R., da Silva, W.C., Carvalho, G.L.O., de Arimatéia Silva, J. and Souza, G.N. (2016) Evaluation of Milk Compositional Quality and Mammary Gland Health of Dairy Herds in the Southwestern Brazilian Amazon. Open Journal of Veterinary Medicine, 6, 139-148. http://dx.doi.org/10.4236/ojvm.2016.69018

Received: April 12, 2016

Accepted: September 24, 2016

Published: September 27, 2016

Copyright $\odot 2016$ by authors and Scientific Research Publishing Inc. This work is licensed under the Creative Commons Attribution International License (CC BY 4.0).

http://creativecommons.org/licenses/by/4.0/

\begin{abstract}
Samples of raw milk from bulk cooling tanks were collected in five municipalities of the Southwestern Brazilian Amazon to establish the prevalence of Staphylococcus aureus and Streptococcus agalactiae, as well as to evaluate the milk composition and its correlation with the bulk tank somatic cell count (BTSCC). A total of 250 samples were collected to investigate the causal agents of bovine mastitis in whole milk, from 50 bulk milk tanks in each municipality. Under laboratory conditions, the samples were diluted to $1 / 10$ and $1 / 100$, and samples of $0.1 \mathrm{ml}$ from each dilution were plated in triplicate on selective media for Staphylococcus aureus and Streptococcus agalactiae. To evaluate the correlation between the major milk components (fat, protein and lactose) and the BTSCC, samples were collected for 18 months from 73 dairy herds. The presence of the above-mentioned contagious mastitis pathogens was detected in $97.2 \%$ (243/250) of refrigerated raw milk samples evaluated. Analysis of the major milk components and BTSCC demonstrated that during the study period, fat component showed the largest variance, followed by protein and lactose, which also showed significant variances.
\end{abstract}

\section{Keywords}

Bulk Tank Somatic Cell Count, Udder Health, Milk Quality, Amazon Region

\section{Introduction}

Brazilian dairy production is spread throughout the country. New dairy cattle centers 
have become established in the Amazon, especially in Rondônia state, located in the Southwestern Amazon. In 2012, the state produced 795,464 million liters, or approximately 2.18 million liters per day [1]. Currently, Rondônia is the major Brazilian milk producer in the Northern region, with $42 \%$ of total production [2].

Mastitis is the most important and economically damaging disease in the dairy industry [3] [4]. The infection results in high economic losses arising from the decrease in the milk production, costs of treatment (drugs and labor), milk discarded following treatment and premature culling of cows [5]. The main microorganisms involved in mastitis are gram-positive cocci, present in over $90 \%$ of the specific pathogen isolates [6] [7]. In Brazilian dairy herds, the most prevalent contagious mastitis pathogens are Staphylococcus aureus and Streptococcus agalactiae [8]-[12].

Isolation of microorganisms in whole milk of herds is only possible when mammary gland infection is present in the herd [13] [14]. The presence of Staphylococcus aureus, which can be isolated from different animal tissues, in whole milk samples is associated with infected mammary glands [15]. Therefore, isolation of Staphylococcus aureus from bulk milk tank samples is considered an indicator of intramammary infection of the herd [14]-[16] because the udder is the only reservoir of the pathogen [14] [17].

Two of the most important objectives of milk analysis are identification of pathogenic microorganisms' presence and determination of the milk components. The diagnosis of mastitis agents can be done by a culture assay of whole milk samples collected within a herd [13] [18]. This technique has been used to isolate specific mastitis pathogens, especially Staphylococcus aureus and Streptococcus agalactiae [18]. Mastitis occurs in clinical and subclinical forms, and is associated with an increased in the somatic cell count (SCC). Measurement of SCC is recognized as a useful tool to monitor udder health and milk quality in dairy cattle herds [14] [19] [20]. The bulk tank SCC (BTSCC) is an indirect measure able in quantity the percentage of infected mammary quarters in herds [21]. It can be used to evaluate the incidence of mastitis because the average SCC in a bulk milk tank is highly correlated with the presence of mastitis in the herd, ranging from 0.50 to 0.96 [22]. A low BTSCC is not only consistently correlated with a low level of mammary gland inflammation, but also with other important milk quality factors, such as microbiological quality (plate counts, preliminary incubation counts, and coliform counts) [23] [24].

The minimum composition parameters of the cooled raw milk sold in Brazil are established by federal regulations. The minimum composition parameters established for milk production in Brazilian dairy farms are $3.00 \%$ fat content, $2.90 \%$ total protein content, and $8.40 \%$ non-fat solids (NFS) content. In terms of mammary gland health, the maximum SCC levels are being gradually reduced in Brazil. The current limit is 3.6 $\times 10^{5} \mathrm{SC} / \mathrm{ml}$, which is considered appropriate for sale of milk and its derivatives [25].

Milk quality studies are incipient for dairy herds established in the Southwestern Brazilian Amazon. The prevalence of the main pathogens involved in mastitis infection is unknown for this region. Thus, the present study attempted to establish the frequency of Staphylococcus aureus and Streptococcus agalactiae infection in the region, as well 
as to correlate the herd milk composition with the SCC of refrigerated milk samples collected in bulk tanks.

\section{Materials and Methods}

\subsection{Characterization of Sample Collection Area}

Samples of refrigerated raw milk were collected in bulk tanks located in the municipalities of the main milk-producing area of Rondônia (Figure 1), located between $10^{\circ} 26^{\prime}$ and $11^{\circ} 43^{\prime}$ south latitude and $62^{\circ} 27^{\prime}$ and $61^{\circ} 54^{\prime}$ west longitude.

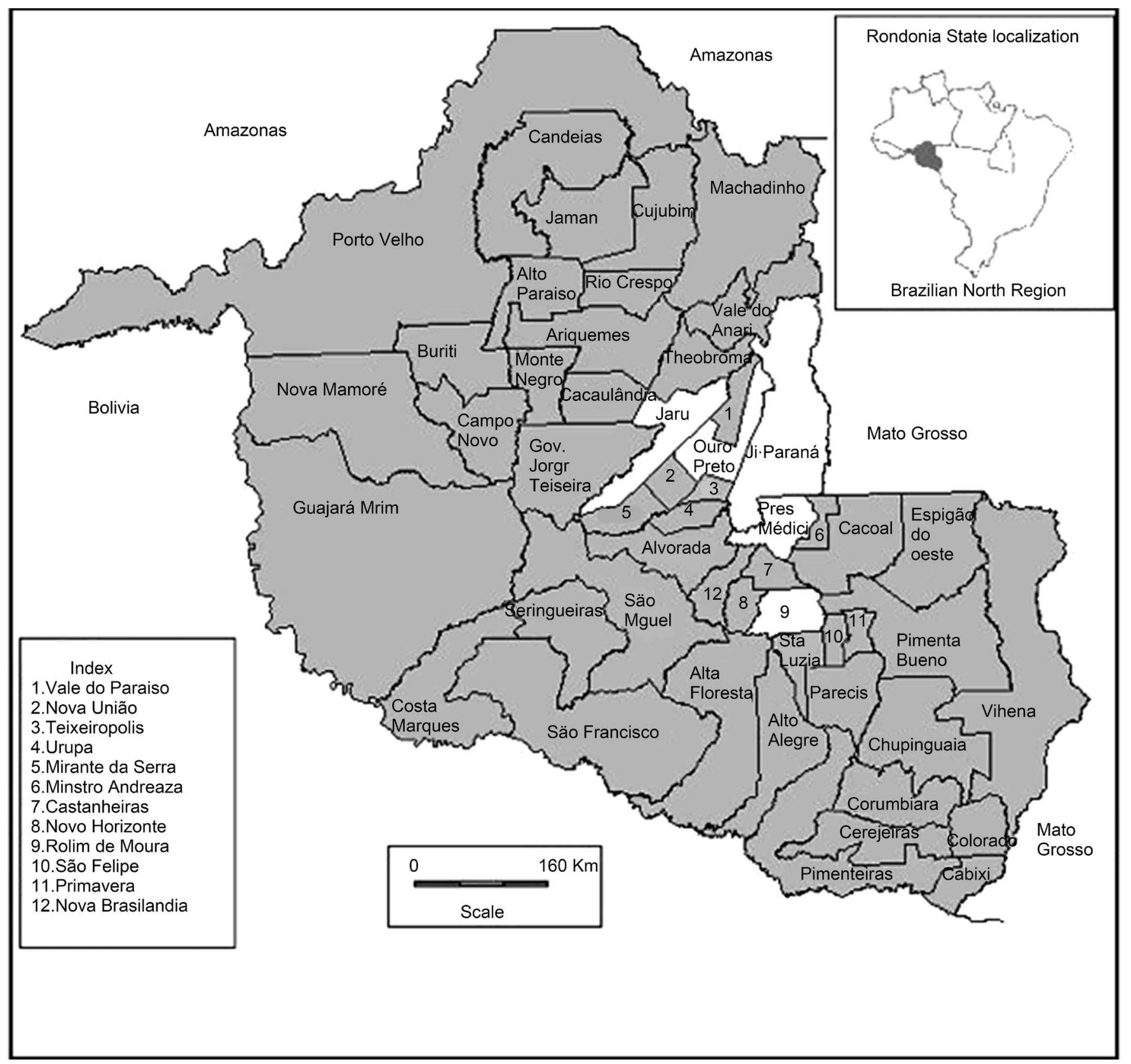

Figure 1. Location of areas where refrigerated raw milk samples were collected in bulk tanks in Rondônia State. 


\subsection{Microbiological Evaluation}

A total of 250 raw milk samples were collected, from 50 bulk milk tanks in each municipality. The minimum sample size was determined considering the confidence level of the result, the desired accuracy level and the expected prevalence of mammary infection in the herds, using the formula for simple random samples recommended by Thrusfield [26] and Noordhuizen et al. [27]:

$$
n=\frac{Z_{\alpha}^{2} \sqrt{P(1-P)}}{d^{2}}
$$

where: $\mathrm{n}=$ number of tanks sampled per municipality,

$Z_{\alpha}^{2}=1.96$ (normal distribution value with confidence level of $95 \%$ ),

$P=$ expected prevalence, and

$d=$ desired accuracy $(\mathrm{p}=5 \%)$.

The procedures recommended by the International Dairy Federation were considered for collection, handling, and maintenance of the milk samples [28]. Samples of refrigerated raw milk stored for approximately $24 \mathrm{~h}$ in bulk tanks were randomly collected and placed in $20 \mathrm{ml}$ sterilized glass jars. Before collection, the milk samples the bulk tanks were stirring for five minutes and then the samples were collected in the top center of the tanks. After collection, the samples were placed in isothermal boxes with ice for shipping. In the laboratory, the samples were diluted in peptonized saline solution to $1 / 10(10-1)$ and $1 / 100(10-2)$, and aliquots with $0.1 \mathrm{ml}$ of milk from each dilution were plated in triplicate on selective media for Staphylococcus aureus and Streptococcus agalactiae. The plates were incubated at $37^{\circ} \mathrm{C}$ for $24 \mathrm{~h}$, when the first bacterial count was performed, followed by further incubation for $24 \mathrm{~h}$ and a second bacterial count.

The identification of Streptococcus agalactiae and Staphylococcus aureus in the raw milk samples was performed with commercial kits: the Streptococcus agalactiae kit ${ }^{\varpi}$ (Probac do Brasil) and Agar Vogel Johnson kit (Probac do Brasil) used according to the manufacturer's recommendations.

\subsection{Evaluation of Total Components of Raw Milk and BTSCC}

Evaluation of the raw milk components and the BTSCC were performed during 18 months during which 73 dairy herds were evaluated. The sampling intervals were about 45 days, resulting in a total of 541 samples evaluated in the period. Means were calculated for fat, protein, NFS, and SCC to evaluate the influence of the dry (May to September) and the rainy (October to April) seasons on milk composition and SSC. The effect of season on the concentrations of fat, protein, and NFS was evaluated by a generalized linear model [29]. Before analysis, the SCC was transformed to base-10 logarithm $(\log 10)$ according to Berglund et al. [30].

\section{Results and Discussion}

\subsection{Microbiological Evaluation of Refrigerated Raw Milk}

The milk samples analyzed with use of selective media to estimate the prevalence of 
Streptococcus agalactiae and Staphylococcus aureus (higher than 94\%) with good accuracy (lower than 5\%) (Table 1).

Of the total of 250 samples evaluated, agents of contagious mastitis (Streptococcus agalactiae or Staphylococcus aureus) were isolated in 243 samples (97.2\%). Streptococcus agalactiae and Staphylococcus aureus together were isolated in 170 samples (68\%), while Staphylococcus aureus alone was isolated in 56 samples (22.4\%) and Streptococcus agalactiae was isolated alone in 17 samples (6.8\%). Only seven milk samples (2.8\%) showed no bacterial growth on the selective media for Streptococcus agalactiae or Staphylococcus aureus (Table 1).

\subsection{Evaluation of Total Components of Raw Milk and BTSCC}

The samples for BTSCC were collected from March 2008 to July 2009. The average concentrations of milk components and the SCC are shown in Table 2. These results indicate that in the study period, the fat component showed the largest variation (approximately $5.0 \%$ ), followed by protein and lactose ( $4.3 \%$ and $2.2 \%$, respectively). The NFS, fat, and protein contents evaluated in all periods were above the minimum thresholds established for milk sale in Brazil. However, there was variation of SCC from 233,000 to 366,000 cells/ml during the monitoring period. These levels are below the maximum limit in Brazil, which is 400,000 cells $/ \mathrm{ml}$.

Although the milk components and the SCC showed values in accordance with the Brazilian rules on milk quality, some samples were outside the legally established thresholds. SCC was the milk quality indicator with the highest percentage of samples above the limits (19.4\%), followed by NFS (13.2\%) and fat contents (8.9\%). The protein content showed the lowest percentage of samples below the established limits for milk quality (6.4\%) (Table 3).

Table 1. Streptococcus agalactiae and Staphylococcus aureus isolated in raw milk samples from bulk tanks in Rondônia's main dairy region.

\begin{tabular}{|c|c|c|c|c|}
\hline \multicolumn{5}{|c|}{ Isolation on selective media } \\
\hline Municipality & $\begin{array}{l}\text { Streptococcus } \\
\text { agalactiae }\end{array}$ & $\begin{array}{l}\text { Staphylococcus } \\
\text { aureus }\end{array}$ & $\begin{array}{c}\text { Streptococcus agalactiae }+ \\
\text { Staphylococcus aureus }\end{array}$ & $\begin{array}{c}\text { No } \\
\text { isolation }\end{array}$ \\
\hline Ji-Paraná & $0 / 50(0 \%)$ & $13 / 50(26 \%)$ & $37 / 50(74 \%)$ & $0 / 50(0 \%)$ \\
\hline $\begin{array}{l}\text { Ouro Preto do } \\
\text { Oeste }\end{array}$ & $0 / 50(0 \%)$ & $8 / 50(16 \%)$ & $42 / 50(84 \%)$ & $0 / 50(0 \%)$ \\
\hline Jarú & $10 / 50(20 \%)$ & $11 / 50(22 \%)$ & $25 / 50(50 \%)$ & $4 / 50(8 \%)$ \\
\hline $\begin{array}{l}\text { Presidente } \\
\text { Médici }\end{array}$ & $3 / 50(6 \%)$ & $0 / 50(0 \%)$ & $47 / 50(94 \%)$ & $0 / 50(0 \%)$ \\
\hline $\begin{array}{l}\text { Rolim de } \\
\text { Moura }\end{array}$ & $4 / 50(8 \%)$ & $24 / 50(48 \%)$ & $19 / 50(38 \%)$ & $3 / 50(6 \%)$ \\
\hline Total & $17 / 250(6.8 \%)$ & $56 / 250(22.4 \%)$ & $170 / 250(68.0 \%)$ & $\begin{array}{l}7 / 250 \\
(2.8 \%)\end{array}$ \\
\hline
\end{tabular}


Table 2. Average values of milk components and somatic cell count (SCC) of milk samples collected between March 2008 and July 2009 in dairy herds raised in Rondônia, Brazil.

\begin{tabular}{ccccccc}
\hline Collection Month & Fat (\%) & Protein (\%) & Lactose (\%) & NFS (\%) & TS (\%) & SCC (cells $\left./ \mathrm{ml}^{-1}\right)$ \\
\hline March 2008 & 4.03 & 3.35 & 4.54 & 8.84 & 12.89 & 233 \\
April 2008 & 3.67 & 3.27 & 4.56 & 8.51 & 12.20 & 265 \\
June 2008 & 3.73 & 3.41 & 4.45 & 8.83 & 12.57 & 259 \\
August 2008 & 3.52 & 3.04 & 4.44 & 8.41 & 11.95 & 328 \\
October 2008 & 3.52 & 3.13 & 4.62 & 8.87 & 12.27 & 276 \\
February 2009 & 3.62 & 3.28 & 4.66 & 8.97 & 12.59 & 292 \\
March 2009 & 3.78 & 3.48 & 4.35 & 8.78 & 12.57 & 263 \\
May 2009 & 3.86 & 3.46 & 4.40 & 8.63 & 12.51 & 254 \\
June 2009 & 3.61 & 3.39 & 4.43 & 8.76 & 12.38 & 290 \\
July 2009 & 3.51 & 3.26 & 4.47 & 8.68 & 12.20 & 366 \\
Mean & $\mathbf{3 . 6 2}$ & $\mathbf{3 . 2 8}$ & $\mathbf{4 . 5 0}$ & $\mathbf{8 . 6 9}$ & $\mathbf{1 2 . 3 1}$ & $\mathbf{2 8 9}$ \\
\hline
\end{tabular}

Table 3. Distribution of milk samples collected in dairy herds in Rondônia in accordance with the limits established by Brazilian milk quality regulations.

\begin{tabular}{cccc}
\hline \multicolumn{2}{c}{ Legal Parameter } & Number of samples collected (n) & $\begin{array}{c}\text { Samples in accordance with the legal } \\
\text { parameters (\%) }\end{array}$ \\
\hline Fat (\%) & $\geq 3.00$ & 484 & 91.2 \\
& $<3.00$ & 47 & 09.8 \\
Protein (\%) & $\geq 2.90$ & 497 & 93.6 \\
& $<2.90$ & 34 & 06.4 \\
NFS (\%) & $\geq 8.40$ & 461 & 86.8 \\
& $<8.40$ & 70 & 13.2 \\
SCC (cells $\left./ \mathrm{ml}^{-1}\right)$ & $\leq 400,000$ & 428 & 80.6 \\
& $>400,000$ & 103 & 19.4 \\
\hline
\end{tabular}

The average of fat observed in the samples was 3.62\% (confidence level of 95\%, $3.58 \%-3.66 \%)$. The SCC results showed significant variation $(\mathrm{P}<0.05)$ in the concentration of milk components (fat, protein and lactose), accounting for $4.0 \%$ to $8.0 \%$ total variation. The milk fat content was not significantly affected by the season. In contrast, the protein and lactose contents significantly changed according to the season $(\mathrm{P}<$ 0.05).

The influence of BTSCC on milk component concentrations can be explained by reduced ability of the breast tissue to synthesize milk components. This situation is caused by lesions caused promoted by mastitis-inducing pathogens in association with the presence of proteolytic and lipolytic enzymes in the udder, secondary to somatic 
cell migration from the blood into the mammary gland tissue [31]. The frequency of Staphylococcus aureus and Streptococcus agalactiae associated with BTSCC values indicates the presence of udders infected with mastitis pathogens. These findings are in accordance with Beaudeau et al. [32], who observed that the presence of pathogenic microorganisms in mammary glands usually results in a somatic cell count $>300,000$ cell/ml. The SCC in milk from a healthy udder quarter should be $<100,000$ cells $/ \mathrm{ml}$ [19] [33].

Physiological factors can increase the cell count in some cases. In udder health monitoring programs, the use of a threshold of 200,000 cells $/ \mathrm{ml}$ to denote the prevalence of subclinical mastitis has been reported [33] [34]. The average SCC of 289,000 cells/ml observed in the dairy herds monitored in Rondônia indicates the presence of a subclinical mastitis among the cows. This is in accordance with the microbiological analysis, which showed a high prevalence of Staphylococcus aureus and Streptococcus agalactiae.

Although microbiological analysis offers advantages, it is important consider that it should not replace the individual clinical assessment of cows' udders in order to verify the presence or not mammary infections. The isolation of etiological mastitis agents using bulk milk samples can be considered a useful tool for monitoring mastitis in control programs, but the results cannot be used to predict the number of infected mammary quarters in a herd [35] [36]. In addition, negative isolation results do not guarantee the absence of contagious mastitis agents in dairy herds.

However, the Staphylococcus aureus and Streptococcus agalactiae isolation found in this monitoring study of quality milk show that the microbiological analysis of bulk milk samples is an efficient tool to assess the presence of etiological mastitis agents in dairy herds. The results observed by Brito et al. [37] in a study of 33 herds, also evaluating the viability of isolating infections agents causing mastitis from whole milk samples, were very similar to those obtained in the present study.

The efficiency of BTSCC to detect the variance in the milk contents can be explained by the reduced ability of the mammary tissue to synthesize milk components. Injuries promoted by mastitis-causing pathogens in association with proteolytic and lipolytic enzymes are probably caused by lesions in the udder that occur by somatic cell migration from the blood into the mammary gland tissue. In light of the findings of Schäellibaum [31], this may be a major factor associated with the variation of milk composition observed in this study.

The present results indicate that the analysis of bulk milk from herds is a viable tool for monitoring udder health in dairy herds. Single samples of bulk milk allowed isolating etiological mastitis agents and tracking the influence of SCC on the composition of milk produced in the analyzed herds. The assessed prevalence of Staphylococcus aureus and Streptococcus agalactiae, as well as the influence of SCC on milk component levels, demonstrates there are important challenges to be overcome by dairy farmers so that the milk produced is in accordance with the sanitary-hygienic limits established by Brazilian regulations. Studies and initiatives aimed at establishing strategies to decrease the prevalence of mastitis and reduce the SCC in dairy herds are promising research 
fields what will help to ensure the sustainability of dairy farming.

\section{Acknowledgements}

The study received financial support from the National Council for Scientific and Technological Development (CNPq, Process No. 554110/2005-9) and Rondônia Dairy Chamber (Proleite). The authors thank Antonio Xavier do Nascimento of the Embrapa Rondônia Animal Health Laboratory for valuable assistance in conducting the laboratory assays and all the technical staff of Emater Rondônia, who helped in collecting of the milk samples used in the study.

\section{Conflict of Interest}

The authors declare there is no conflict of interest regarding the publication of this article.

\section{References}

[1] Instituto Brasileiro de Geografia e Estatística-IBGE (2012) Sistema IBGE de Recuperação Automática-SIDRA. http://www.sidra.ibge.gov.br/bda/default.asp?t=2\&z=t\&o=1\&u1=1\&u3=1\&u4=1\&u5=1\&u6= 1\&u7=1\&u8=1\&u9=1\&u10=1\&u11=1\&u12=3\&u13=1\&u14=26674\&u15=1\&u16=1\&u2=11

[2] Instituto Brasileiro de Geografia e Estatística-IBGE (2011) Sistema IBGE de Recuperação Automática-SIDRA.

http://www.sidra.ibge.gov.br/bda/default.asp?t=2\&z=t\&o=1\&u1=1\&u2=1\&u3=1\&u4=1\&u5 =1\&u6=1\&u7=1\&u8=1\&u9=1\&u10=1\&u11=1\&u12=3\&u13=1\&u14=26674\&u15=1\&u16=1

[3] Alert, C. (1995) Mastitis Vaccines: Alternative Strategies for Control of Environmental Mastitis. Large Animal Veterinary, 50, 10-14.

[4] Kossaibati, M.A. and Esslemont, R.J. (1997) The Costs of Production Diseases in Dairy Herds in England. Veterinary Journal, 154, 41-51.

http://dx.doi.org/10.1016/S1090-0233(05)80007-3

[5] Miller, R.H., Paape, M.J., Fulton, L.A. and Schutz, M.M. (1993) The Relationship of Milk Somatic Cell Count to Milk Yields for Holstein Heifers after First Caving. Journal of Dairy Science, 76, 728-733. http://dx.doi.org/10.3168/jds.S0022-0302(93)77396-8

[6] Ericsson Unnerstad, H., Lindenberg, A., Waller, K.P., Ekman, T., Artursson, K., NilssonÖst, M. and Bengtsson, B. (2009) Microbial Etiology of Acute Clinical Mastitis and AgentSpecific Risk Factors. Veterinary Microbiology, 137, 90-97. http://dx.doi.org/10.1016/j.vetmic.2008.12.005

[7] Sharif, A., Umer, M. and Muhammad, G. (2009) Mastitis Control in Dairy Production. Journal of Agriculture \& Social Sciences, 5, 102-105.

[8] Barbalho, T.C.F. and Mota, R.A. (2001) Isolation of Bacterial Agents Associated with Subclinical Mastitis in Bovine in the State of Pernambuco. Brazilian Journal of Animal Health and Production, 2, 31-36.

[9] Voltolini, T.V., dos Santos, G.T., Zambom, M.A., Ribas, N.P., Müller, E.E., Damasceno, J.C., Itavo, L.C.V. and Veiga, D.R. (2001) Influence of Lactation Stages on the Counting of Somatic Cells of Holstein Milk Cows and Identification of Sources of Mastitis Pathogens in Cattle. Acta Scientiarum, 23, 961-966.

[10] Ribeiro, M.E.R., Petrini, L.A., Aita, M.F., Balbinotti, M., Stumpf Jr., W., Gomes, J.F., 
Schramm, R.C., Martins, P.R. and Barbosa, R.S. (2003) Relation between Clinical, Subclinical Infectious and Non-Infectious Mastitis in Milk Production Units in the Southern Region of Rio Grande do Sul State. Brazilian Journal of Agroscience, 9, 287-290.

[11] Arcuri, E.F., Brito, J.R.F., Pinto, S.M., Angelo, F.F. and Souza, G.N. (2006) Microbiological Quality of Refrigerated Milk on Farms. Brazilian Journal of Veterinary and Animal Sciences, 58, 440-446.

[12] Freitas, M.F.L., Luz, I.S., Silveira-Filho, V.M., Pinheiro-Junior, J.W., Stanfford, T., Mota, R.A., Sena, M.J., Almeida, A.M.P., Balbino, V.Q. and Leal-Balbino, T.C. (2008) Staphylococcal Toxin Genes in Strains Isolated from Cows with Subclinical Mastitis. Brazilian Journal of Veterinary Research, 28, 617-621. http://dx.doi.org/10.1590/S0100-736X2008001200010

[13] Godkin, M.A. and Leslie, K.E. (1993) Culture of Bulk Tank Milk as a Mastitis-Screening Test: A Brief Review. Canadian Veterinary Journal, 34, 601-605.

[14] Brito, M.A.V.P., Brito, J.R.F., Ribeiro, M.T. and Veiga, V.M.O. (1999) Dairy Herds Pattern of Intramammary Infection: Evaluation of All Mammary Quarters of Lactating Cows. Brazilian Journal of Veterinary and Animal Sciences, 51, 33-35.

[15] Roberson, J.R., Fox, L.K., Hancock, D.D., Gay, J.M. and Besser, T.E. (1994) Ecology of Staphylococcus aureus Isolated from Various Sites on Dairy Farms. Journal of Dairy Science, 77, 3354-3364. http://dx.doi.org/10.3168/jds.S0022-0302(94)77277-5

[16] Riekerink, R.G.M.O., Barkema, H.W., Veenstra, S., Poole, D.E., Dingwell, R.T. and Keefe, G.P. (2006) Prevalence of Contagious Mastitis Pathogens in Bulk Tank Milk in Prince Edward Island. Canadian Veterinary Journal, 47, 567-572.

[17] Andersen, H.J., Pedersen, L.H., Aarestrup, F.M. and Chriel, M. (2003) Evaluation of the Surveillance Program of Streptococcus agalactiae in Danish Dairy Herds. Journal of Dairy Science, 86, 1233-1239. http://dx.doi.org/10.3168/jds.S0022-0302(03)73707-2

[18] Farnsworth, R.J. (1993) Microbiologic Examination of Bulk Tank Milk. Veterinary Clinics of North American: Food Animal Practice, 9, 469-474. http://dx.doi.org/10.1016/s0749-0720(15)30614-9

[19] Hamann, J. (2002) Relationships between Somatic Cell Counts and Milk Composition. Bulletin of the International Dairy Federation, 372, 56-59.

[20] Schwarz, D., Diesterbeck, U.S., Failing, K., König, S., Brügemann, K., Zschöck, M., Wolter, W. and Czerny, C.P. (2010) Somatic Cell Counts and Bacteriological Status in Quarter Foremilk Samples of Cows in Hesse, Germany-A Longitudinal Study. Journal of Dairy Science, 93, 5716-5728. http://dx.doi.org/10.3168/jds.2010-3223

[21] Philpot, W.N. and Nickerson, S.C. (1991) Mastitis: Counter Attack: A Strategy to Combat Mastitis. Badson Brothers Co., Illinois.

[22] Emanuelson, U. and Funke, H. (1991) Effect of Milk Yield on Relationship between Bulk Milk Somatic Cell Count and Prevalence of Mastitis. Journal of Dairy Science, 74, 24792483. http://dx.doi.org/10.3168/jds.S0022-0302(91)78424-5

[23] Reneau, J.K. (2001) Somatic Cell Counts: Measures of Farm Management and Milk Quality. 40 th Annual Meeting National Mastitis Council, National Mastitis Council, Verona, 11-14 February 2001, 29-37.

[24] Schukken, Y.H., Leslie, K.E., Weersink, A.J. and Martin, S.W. (1992) Ontario Bulk Milk Somatic Cell Count Reduction Program. 1. Impact on Somatic Cell Count and Milk Quality. Journal of Dairy Science, 75, 3352-3358. http://dx.doi.org/10.3168/jds.S0022-0302(92)78111-9

[25] Brasil (2011) Ministério da Agricultura, Pecuária e Abastecimento. Instrução Normativa 
No. 62, de 29 de dezembro de 2011, Altera a Instrução Normativa MAPA No. 51, de 18 de setembro de 2002, Diário Oficial da União, Brasília, Seção 1, 6.

[26] Thrusfield, M. (1995) Veterinary Epidemiology. 2nd Edition, Blackwell Science, Cambridge.

[27] Noordhuizen, J.P.T.M., Frankena, K., Van Der Hoofd, C.M. and Graat, E.A.M. (1997) Application of Quantitative Methods in Veterinary Epidemiology. Wageningen Press, Wageningen.

[28] International Dairy Federation (IDF) (1985) Milk and Milk Products-Methods of Sampling. International Standard 50B, Brussels, $19 \mathrm{p}$.

[29] Dohoo, I., Martin, W. and Stryhn, H. (2003) Veterinary Epidemiologic Research. Atlantic Veterinary College, Charlottetown, $706 \mathrm{p}$.

[30] Berglund, I., Pettersson, G., Östensson, K. and Svennersten-Sjaunja, K. (2007) Quarter Milking for Improved Detection of Increased SCC. Reproduction in Domestic Animals, 42, 427-432. http://dx.doi.org/10.1111/j.1439-0531.2006.00803.x

[31] Schäellibaum, M. (2000) Effects of High Somatic Cell Count on the Yield and Quality of Cheeses. Proceedings of 2 nd International Symposium of Milk Quality, Curitiba, 21-26.

[32] Beaudeau, F., Fourichon, C. and Seegers, H. (2002) Risk of Clinical Mastitis in Dairy Herds with a High Proportion of Low Individual Milk Somatic-Cell Counts. Preventive Veterinary Medicine, 53, 43-54. http://dx.doi.org/10.1016/S0167-5877(01)00275-6

[33] Hillerton, J.E. (1999) Redefining Mastitis Based on Somatic Cell Count. Bulletin of the International Dairy Federation, 345, 4-6.

[34] Harmon, R.J. (1994) Physiology of Mastitis and Factors Affecting Somatic Cell Counts. Journal of Dairy Science, 77, 2103-2112. http://dx.doi.org/10.3168/jds.S0022-0302(94)77153-8

[35] González, R.N., Jasper, D.E., Bushnell, R.B. and Farver, T.B. (1986) Relationship between Mastitis Pathogen Numbers in Bulk Tank Milk and Bovine Udder Infections in California Dairy Herds. Journal of the American Veterinary Medical Association, 189, 442-445.

[36] Bartlett, P.C., Miller, G.Y., Lance, S.E. and Heider, L.E. (1991) Use of Bulk Tank and Milk Filter Cultures in Screening for Streptococcus agalactiae and Coagulase-Positive Staphylococci. Journal of Food Protection, 54, 848-851.

[37] Brito, M.A.V.P., Brito, J.R.F., Souza, H.M. and Vargas, O.L. (1998) Evaluation of the Sensitivity of Bulk Tank Milk Cultures for the Isolation of Contagious Bovine Mastitis Pathogens. Brazilian Journal of Veterinary Research, 18, 39-44. 
Submit or recommend next manuscript to SCIRP and we will provide best service for you:

Accepting pre-submission inquiries through Email, Facebook, LinkedIn, Twitter, etc. A wide selection of journals (inclusive of 9 subjects, more than 200 journals)

Providing 24-hour high-quality service

User-friendly online submission system

Fair and swift peer-review system

Efficient typesetting and proofreading procedure

Display of the result of downloads and visits, as well as the number of cited articles

Maximum dissemination of your research work

Submit your manuscript at: http://papersubmission.scirp.org/

Or contact ojvm@scirp.org 